\title{
NYITRAI FERENCNÉ: PRIORITÁSOK GAZDASÁGUNK FEJLESZTÉSÉBEN
}

(Kossuth Könyvkiadó, Budapest, 1986. 271 p.)

A szerzőnck az 1980-as években megjelent, Immár harmadik könyve a népgazdaságunk fejlesztésében érvényesült prioritásokat tủzte célul áttekinteni. Időszerúségét aláhúzza az a tény is, hogy az elemzés tárgyául választott témakör a ritkán vizsgált kérdések közé tartozik. A széles körü szakmai érdeklődésre \$zámottartó munka azt mutatja be, hogy az elmúlt másfél évtizedben milyen prioritások ervényesültek hazánkban, hogyan alakult ezek szerepe az 1978 decemberében elhatározott pályamódosítás után. A szerző hangsúlyozza, hogy a gazdasági élet különbözó fejlettségi szintjén lévő országokban (és egy országon belül is az elért fejlettség egyes szakaszaiban) eltérổ fejlesztési sorrend érvényesül. A fejlödés kezdeti szakaszában még a lakosság anyagi szükségleteinek mennyiségi kielégítése a fö feladat, a fejlódés előrehaladtával azonban már nem ilyen egyértelmúek a prioritások. Hz a meghatározásukra és érvényesülési módjukra egyaránt vonatkozik.

A különbözó időszakokban érvényesülő prioritások körvonalazása és hatásmechanizmusuk vizsgálata igen bonyolult feladat. Nem egyszerü összevetni a valóságban ténylegesen bekövetkező folyamatokat a prioritásként meghirdetett feladatokkal. Nem lehet mindig élesen elválasztani a prioritások és kísérójelenségeik hatásait a gazdaságban érvényesü ló egyéb tényezók által indukált folyamatokétól, a különböző irányban és mértékben ható tényezók bonyolult szövevényéból nem lehet kiragadni, élesen megvilágítani azokat az elemeket, amelyek a gazdasági és a politikai vezetés szándékait tükrözik. (Ezért a szerző szerényen úgy fogalmaz, hogy munkájában a legfőbb tendenciákat igyekszik felvázolni.)

Elönyben csak akkor lehet valamit részesiteni, ha megfelelóen választjuk ki, és ez nem túl széles terület. Szükség van a megfelelö, pontos körülírásra, mert e nélkül óhatatlanu1 skélesítjuk az elónyben részesítendớk körét. (Az elmúlt években ezeket a szempontokat nem mindig vettük figyelembe.) A mellékhatusok is sajátos problémákat vethetnek és vetnek fel. Fontos, hogy jól célozzuk meg a prioritásban részesítendó, lehetőleg homogén tevékenységeket. Ha nem így járunk el, akkor nem érjük el a kívánt célt. Erre ismert az a gyakorlatunk, amikor a prioritás inhomogén szervezetekre irányul, s így keretei között olyan tevékenységfajtákat is fejlesztenek, amelyek egyébként nem tartoznának a figyelem fókuszába. A dolog másik oldala viszont az, hogy minden prioritásrendszer megbontja a harmónikus, egymásra épített, összehangolt fejlesztési menetet. E megbontás ugyan tudatos, de nem foglalkozunk idôben és megfelelöen a létrehozott diszharmónia felszámolásával. Az összhang csak input-output szemlélettel, az összes kölcsönhatások és következmények figyelembevételével érhető el.

A hatalmas tényanyagot tartalmazó, a kérdéskört nagy mélységben elemzó igényes munka legfớbb célja, hogy a múlt jelenségeiból, folyamataiból és tendenciáiból elóremutató következtetéseket vonjon le, megválaszolja azt a kérdést, hogy a prioritások jelenleg érvenyesített módszerei milyen mértékben váltak és válnak be a gazdaság gyakorlatában. A szerző a címben foglaltnál lényegesen több kérdésben mond új, érdekes információt. Lényeget kiemelő, gondosan összeállított táblázatai jól alátámasztják a mondanivalót.

A könyv tíz fejezetben tárgyalja a témakörre vonatkozó kérdéseket. A Kitekintés a világba címú elsó fejezet a gazdaság különbözó vezérlési módszereit foglalja össze. Bemutatja a szocialista országok tervgazdálkodási gyakorlatán belül érvényesülô szigorúbb és kevésbé kötött formák széles választékát, és a tốkés országok hivatalosan meghirdetett iparpolitikájához történő eltérő viszonyulást. Külön szól az Amerikai Egyesült Âllamokban kialakult eltérố nézetek érvényesüléséről és a fejlettség alacsonyabb szintjén lévó országokat jellemző, viszonylag erősebb központi ráhatás alakulásáról.

A második egység a hazai helyzetet elemzi, ezen belül a tervek szerepét, a struktúrapolitikai határozatokat, valamint a prioritás új elemeit a nyolcvanas években. Külön fejezet taglalja az egyensúly javítása, hely reállítása kérdését. Ha gazdasági prioritáskẻnt az egyensúly helyreállításáról van szó, akkor a 
külkereskedelmi egyensúlyon minimálisan a fizetési mérleg egyensúlyát, ezen belül a legfontosabb elemet, a külkereskedelmi mérleg egyensúlyát, továbbá a vásárlóerő és az árualapok egyensúlyát, a beruházásokhoz és a fejlesztéshez rendelkezésre álló eróforrások összhangját, valamint az állami költségvetés egyensúlyát kell érteni. „A nyolcvanas évek közepén kialakult gazdasági és társadalmi prioritások összecsengenek. A gazdaság intenzív szakaszára való áttérés nem mennyiségben több, hanem minóségileg jobb teljesítményt igényel" - írja a szerző (p. 65.).

Ơnálió egység taglalja a központi fejlesztési programokat (KFP), majd külön értékeli azokat a szerző a hetvenes és a nyolcvanas években. Kiemelt kérdésként szerepelnek a ráfordítás-orientảlt programok. A szerző elemzi az energiagazdálkodási KFP-t, a hulladék- és másodhasznositás, illetve a gazdaságos anyagfelhasználás és a technológiák korszerúsítésének központi fejlesztési programját, szól az elektronikai alkatrészek és részegységek központi fejlesztési programjáról, valamint az elektronika társadalmi-gazdasági alkalmazása elterjesztésének gazdaságirányitási feladatait átfogó központi gazdaságfejlesztési és szervezési programról. Foglalkozik a szerzó a központi gazdaságfejlesztési programok hatásával, jövóbeni szerepével. Hangsúlyozza, hogy ezek a programok a prioritások megtestesítőjeként nemcsak a gazdaság területén müködnek, hanem egyre sikeresebben fejtik ki hatásukat a társadalmi célok megvalósítása érdekében is. Végủl következtetéseket von le arra vonatkozóan, hogy a szóbanforgó programok mennyiben váltak a gazdaság hajtóeróivé.

Az igen érdekes, sok hasznosítható mondanivalót tartalmazó könyv joggal kelti fel a szakmai körök és a társadalmi-gazdasági kérdések iránt fogékony olvasók érdeklődését.

Abonyiné Palotás Jolên

\title{
ÖRSZIGETHY ERZSÉBET: ASSZONYOK FÉRFISORBAN
}

\author{
(Szépirodalmi Könyvkiadó, Budapest, 1986. 297 p.)
}

A népviseletbe öltözött, egymásba fogódzó, kérges tenyerú hévizgyörki asszonyok ismerösen köszönnek ránk a „Magyarország felfedezése" sorozat legújabb könyvének borítólapjáról. Egy korábbi, a „Folyamatos jelen" c. kötetben, rövid tanulmány erejéig már bepillantást nyerhettünk életükbe ŌRSZIGETHY Erzsébet jóvoltából. A szerzó most, összegezve sokéves kutatómunkája tapasztalatait, felvázolta Hévízgyörk társadalomrajzát. Nem volt szándékában monográfiát írni s a község minden rétegére kiterjedó szociológiai elemzést végezni. Részletesen megismerhetjük azonban a hetvenes évek zöldségtermeló, piacos életû faluját. Ennek alapján kirajzolódnak az itt végbemenô folyamatok egyedi és általánosítható vonásai s a település túlélési stratégiái.

Hévízgyörk a Galga mentén, Budapesttool 50 kilométerre fekszik. A nagyváros közelsége jelentősen befolyásolja fejlödési pályáját. BELUSZKY P. - SIKOS T. T. tipológiája szerint a „lakóövezet közepes nagyságú, lakó-agrár- funkciójú, stagnáló népességü falvai" közé tartozik. Ezt támasztják alá a statisztikai adatok is. A népességszám 1980-ban érte el maximumát (3064 fő), a növekedés azonban csekély mértékü, 30 év alatt mindössze $10 \%$-os volt. Az agrárfunkciót jelzi a mezógazdasági keresók $21 \%$-os aránya (sajnálatos módon, valamilyen sajtóhiba folytán a könyvben ez a szám 4\%-ra redukálódott). Végezetül a lakófunkció is nyilvánvaló, ha figyelembe vesszük, hogy az aktív keresók közel 85\%-a a falun kívül talál munkát. Legnagyobb részük, több mint 800 emiber, naponta ingázik a fóvárosba.

ÓRSZIGETHY Erzsébet szociográfiája túlmutat a számokon, s továbbgondolásra késztet: vajon indokolte csupán a ,város szemszögéból" vizsgálnunk az ilyen településeket, s egyszerủen lakóövezeti falvaknak tekintetni azokat? A szerzó maga is hasonló kérdéseket feszeget. Mi az oka Hévizgyörk kétarcúságának, vagy is annak, hogy egyszerre mutatja egy agglomerációs, ugyanakkor egy hagyományos 